NBER WORKING PAPER SERIES

TAKING TRADE POLICY SERIOUSLY: EXPORT SUBSIDIZATION AS A CASE STUDY IN POLICY EFFECTIVENESS

\author{
Dani Rodrik
}

Working Paper No. 4567

\author{
NATIONAL BUREAU OF ECONOMIC RESEARCH \\ 1050 Massachusetts Avenue \\ Cambridge, MA 02138 \\ December, 1993
}

This is a revised version of a paper prepared for the conference on New Directions in Trade Theory, Ann Arbor, October 29-30, 1993. I am grateful to IRIS and to the CEPR MIRAGE Project for financial support, and to Neeraja Sivaramayya for research assistance. Robert Baldwin, Sharyn O'Halloran, and David Richardson have made valuable suggestions. I have also received generous help from Jagdish Bhagwati, Merih Celâsun, Gerry Helleiner, Kathie Krumm, Nat Leff, Juan-Antonio Morales, Helen Shapiro, and Sübidey Togan, who directed me to sources and in some cases provided them. This paper is part of NBER's research program in International Trade and Investment. Any opinions expressed are those of the author and not those of the National Bureau of Economic Research. 


\title{
TAKING TRADE POLICY SERIOUSLY: EXPORT SUBSIDIZATION AS A CASE STUDY IN POLICY EFFECTIVENESS
}

\begin{abstract}
In thinking about policy, academic economists alternate between theoretical models in which govemments can design finely-tuned optimal interventions and practical considerations which usually assume the government to be incompetent and hostage to special interests. I argue in this paper that neither of these caricatures is accurate, and that there is much to be leamed by undertaking systematic, analytical studies of state capabilities -- how they are generated and why they differ across countries and issue areas. Case studies of export subsidization in Korea, Brazil, Turkey, India, Kenya, and Bolivia are presented to confront usual presumptions against actual experience. Contrary to conventional wisdom, the successful cases (Korea and Brazil) turn out to be ones in which the government exercised discretion and selectivity, while the most uniform and non-discretionary cases (Kenya and Bolivia) were clear failures. The paradox is explained in terms of state autonomy and policy coherence.
\end{abstract}

\author{
Dani Rodrik \\ Columbia University \\ 420 West 118 th Street \\ New York, NY 10027 \\ and NBER
}


TAKING TRADE POLICY SERIOUSLY:

\section{EXPORT SUBSIDIZATION AS A CASE STUDY IN POLICY EFEECTIVENESS}

\section{Introduction}

Trade theorists' approach to trade policy has always been somewhat schizophrenic. Theorists make their mark by working out in elaborate detail new ways in which policy interventions can enhance national well-being. This tradition extends from Bhagwati's (1971) exhaustive categorization of distortions and appropriate policy responses to the more recent work on "strategic" trade policy (Brander and Spencer, 1985; Krugman, 1984; see also McCulloch, 1993). On the other hand, most trade theorists would recoil in horror at the thought that a government may take them seriously, and attempt to implement the finely-tuned subsidies or tariffs that their theories often call for. The image of government that most trade economists carry with them is of one that is fundamentally incompetent and, worse still, hostage to special interests. While this contrast exists in all branches of economics, it is perhaps sharpest in international trade, because the desirability of free trade is so sacrosanct.

In many of the standard models, the government is viewed as omniscient and omnipotent, achieving any desired result with the stroke of a pen. These models obviously demand too much of the government. Their policy conclusions can be easily weakened (and sometimes reversed) by considering informational constraints or alternative strategic assumptions. This tradition is exemplified by papers such as Eaton and Grossman's (1986) treatment of strategic export subsidization, Dixit's (1989) criticism of models of tariffs as social insurance, and Carmichael's (1987) modelling of U.S. export credit subsidies. A somewhat different but equally damnning literature focuses on the unintended, if predictable, consequences of 
trade policy, such as the migration of production to third countries to evade country-specific quotas or quality upgrading in response to quantitative restrictions. Baldwin (1982) provides a thorough compendium of such unintended results.

But fundamentally the trade economist's suspicions of trade policy transcend these technical considerations. These suspicions are more deeply rooted in a general skepticism regarding the ability of governments to act in the common good, rather than as an instrument of special interests. Hence, Krugman (1993) draws a distinction between what he calls "narrow" and "broad" arguments for free trade: "The broad argument for free trade, to which many economists implicitly subscribe, is essentially political: free trade is a pretty good, if not perfect policy, while an effort to deviate from it in a sophisticated way will probably end up doing more harm than good" (Krugmer, 1993, 364). Or as Grossman (1987, 65) puts it: "the market failures in the political realm might easily outweigh those in the economic realm, leaving us with a set of strategic trade policies that would serve only the interests of those fortunate enough to gain favor." Hence, the preference for laissez-faire is based fundamentally on political reasoning of a certain type, leading in. turn to a specific presumption about the capability of states to deliver effective policies.

This particular presumption--that states lack the capacity to deliver appropriate policies--may be correct in most contexts. The trouble is that it may also be false. We don't know, because trade economists rarely concern themselves for long with policy formulation and implementation. Standards of evidence and substantiation are notoriously weak in the trade literature when it comes to 
effectiveness of actual policies; anecdote and stylized fact are easily merged and woven around formal models, providing support for whatever theoretical demonstration is at hand. And appeals to political-economy arguments for non-intervention are more often than not simply a whole lot of hand-waving.

A more appealing starting point is to grant that that there exists such a thing called "state capability", that some states may be adequately endowed with it, that others may not be, and that state capabilities can sometimes be enhanced where they are lacking. This broadened perspective may then allow us to use economists' tools to attempt to understand when policy is effective and why. This paper represents one small step in this research agenda. In what follows, I will draw on evidence on the use of one particular policy--export subsidization--in a variety of countries to highlight a number of interesting issues, puzzles, and findings that emerge when we start to take trade policy seriously.

None of the above should be construed to imply that there is a dearth of research on the effectiveness of policy, and on state capabilites more broadly. Far from it. To cite one significant strand of thought, the extent to which states can act "autonomously" in formulating and implementing policy has long been a central concern in the political science literature. ${ }^{2}$ I will draw on some of this work

'As will become clear, my focus is on effectiveness rather than efficiency (in the economist's sense) of policy. I do not ask whether a certain policy was beneficial or not, simply whether it produced the intended result. Analysis of efficiency is contingent on an analysis of effectiveness.

${ }^{2}$ Peter Evans, a sociologist, writes $(1992,141)$ : "Recognition of the importance of state capacity, not simply in the sense of of the prowess and perspicacity of technocrats within the state apparatus but also in the sense of an institutional structure that is durable and effective, is characteristic of the third wave of thinking about the 
below. In addition, there is a literature oriented towards developing rules-of-thumb for practitioners, mostly generated at (or by) the World Bank (see, for example, Thomas and Nash, 1991a). What is lacking is serious engagement by academic economists--even those interested in policy--in research on these issues. That is a pity for two reasons. First, economists' analytical toolkit and parsimonious approach to understanding the real world may have much to contribute to this area. ${ }^{3}$ Second, unless economists devote this effort, their models of policy are condemned to remain naive.

The rest of this paper is organized as follows. Section II contains a preliminary discussion of the determinants of policy effectiveness. I next turn to two successful cases of export subsidization (Korea and Brazil, section III), followed by two failures (Kenya and Bolivia, section IV), and two intermediate cases (India and Turkey, section $\mathrm{V}$ ). A concluding discussion and some comments on the U.S. case are presented in Section VI.

state and development." By the first and second waves, Evans is referring to the conceptions of the state as an effective agent of change and as a hindrance, respectively. For a recent survey of the political science and sociology literature on the state, see Barkey and Parikh (1991).

\footnotetext{
${ }^{3}$ The more time I spent with the political science literature on state autonomy (mentioned above and discussed below), the more convinced I became of this point. To an economist, this literature appears as remarkably lacking in concreteness, transparent cause-andeffect relationships, and (in principle) testable hypotheses, not to mention practical guidance. On the other hand, Sharyn o'Halioran has reminded me that there is a sizable recent literature in American politics that pays close attention to issues of institutional design, often drawing on economists' tools. An application of this literature to comparative policy issues may well prove to be a productive effort.
} 


\section{Preliminary Considerations}

A good starting point is to consider the models that we do have with some relevance to a discussion of state capability and policy effectiveness. There are three sets of economic models that I think are invaluable in thinking about policy formulation and implementation: (i) models of dynamic-inconsistency of policy; (ii) models with irreversibilities and hysteresis; and (iii) models of rent-seeking. Each of these has a distinct lesson for what makes policy effective.

The basic model of dynamic inconsistency points to the costs of discretionary behavior by government officials and brings out the advantage of rule-based policy regimes which entail high degrees of pre-comitment. Two significant applications of these ideas in the area of trade policy can be found in Staiger and Tabellini (1987) and Matsuyama (1990). The first of these papers shows the bias towards excessive protection on the part of governments that care about income distribution, while the second demonstrates the difficulties of disciplining firms by threatening to remove protection, a threat that is hardly credible ex post. In each case, a clear implication is that designing schemes that would enhance policy makers' commitment to exante rules would be desirable.

Models with irreversibilities demonstrate the importance of policy stability, or more accurately, predictability in coaxing the desired response from the private sector. When supply decisions are subject to sunk costs, unpredictability about future policy can seriously dampen the supply response to any policy change (Dixit, 1989; Pindyck and Solimano, 1993), and potentially render a primafacie desirable policy change harmful (Rodrik, 1991). Combined with 
Calvo's (1989) demonstration that a lack of credibility in trade policy amounts to an intertemporal distortion, this literature underscores the importance of building predictability into the policy making process.

Finally, the rent-seeking approach to trade policy, originating from Krueger's (1974) venerable article, reminds us that policies that create rents will also create rent-seekers. This in turn generates incentives for bureaucrats to create rents in the first place (Shleifer and vishny, 1991). These ideas lie at the core of the neoclassical political-economy literature on trade policy, where rentseeking interest groups and rent-providing policy marers interact to produce inefficient policy configurations (Grossman and Helpman, 1992, provide a recent example). The implications are bleak for policy making: policy interventions should be avoided as a rule, but if they cannot, they should be undertaken in a manner that keeps private groups at arms' length.

Taken together, these theoretical ideas yield quite a coherent story about what constitutes a good policy regime. Successful government programs are likely to contain the following characteristics:

- they apply simple and uniform rules, rather than selective and differentiated ones;

- they endow bureaucrats with few discretionary powers;

- they contain safeguards against frequent, unpredictable alteration of the rules;

- they keep firms and other organized interests at arms'

"Although, they also allow the government tc place an exogenous weight on aggregate efficiency. 
length from the policy formulation and implementation process.

These conclusions seem broadly reasonable, and lists like the above are often drawn in policy discussions.

When I first decided to take on export subsidies as a case study, I was expecting that the evidence on what makes some programs succcessful and others failures would validate these conclusions. I was wrong. While the models mentioned above are useful in understanding what happens, the broad generalizations that one is tempted to draw from them are much less so. In fact, as a first cut, these broad conclusions have more explanatory power when they are turned upside down! The two most successful programs of export subsidization I found, those in South Korea and Brazil, were highly complex and selective, differentiated by firm, subject to frequent changes, gave bureaucrats enormous discretionary powers, and entailed close interaction between bureaucrats and firms. On the other hand, the least successful programs in my sample, those in Kenya and Bolivia, consisted of simple, across-the-board, and non-selective subsidies.

What is going on here? I think the answer is that there is a lot that we do not know or understand about state capabilities and policy effectiveness. This underscores the point made in the introduction about the need to get economists seriously engaged in these issues.

With regard to export subsidies, there are two concepts that I have found useful in characterizing the differences in outcomes across countries. The first, and more fundamental, one is the notion of state autonomy. This refers to the degree to which the state and administrative apparatus of a society is insulated from organized 
private interests, and consequently can exercise discipline over them. ${ }^{5}$ The second useful notion is that of policy coherence, meaning a clearly articulated, stable, and non-conflicting set of policy priorities. I will be using these terms in a descriptive, rather than explanatory, fashion, as it remains unclear whether they can be operationalized in a meaningful manner.

The evidence from the case studies point to some simple conclusions. Policies work best when autonomy and coherence are both present; they fail when neither is. However, policy coherence on its own is worth something: coherent programs can be successfully formulated and implemented even when autonomy is lacking, but at the cost of some abuse. One important implication for economic analysis is the following: while the state may not be an omniscient socialwelfare maximizer, neither is it a tool of lobbying groups as in much of the recent political-economy literature. To understand where each case fits, we have to dig deeper than we are prone to do.

As mentioned above, the concept of state autonomy is borrowed from the political science literature. However, it has an important antecedent in Gunnar Myrdal's magisterial work on Asian development, Asian Drama (1968). In his study of Asian societies, Myrdal was struck by how little states asked of their citizens, and how incapable they were of eliciting compliance when they tried. The result was a pattern of economic policy making that was all carrots and no stick. Myrdal christened such states as "soft states", and contrasted them with their opposite, "strong states". This distinction, under different names, has survived. For example, Jones and Sakong's (1980)

${ }^{5}$ Occasionally the literature draws a distinction between the two parts of this definition, referring to the first as "autonomy" and the second as "capacity". See Barkey and Parikh (1991, 525-26). 
excellent study of policy making in South Korea harks back to this distinction, and the authors locate the key to that country's stellar performance in the presence of a "hard" state (more on this below).

state autonomy, as the term is usually used, is effectively a measure of how "strong" or "hard" a state is. Migdal (1988) is a good source on how political scientists have approached the issue of state strength and societal control, as well as on attempts to quantify these concepts. I find it helpful to think of autonomy as the extent to which the state can act as a Stackelberg leader cier private groups, rather than as a Stackelberg follower; states that fall in the first category are strong, while states in the second category are weak. ${ }^{6}$ The existing literature is not very helpful on where autonomy comes from and how it is acquired. Most studies point to distinctive historical experience: Migdal (1988), for example, emphasizes massive social dislocations, such as war, revolution, or mass migration, as a precondition to the existence of strong states.'

Going back to our list of what constitutes a good policy regime, then, these conclusions turn out to be too pessimistic about state capabilities in societies governed by strong states. On the other hand, they are too optimistic about the capabilities of weak states-and that is really bad news! In either case, they provide a bad fit.

${ }^{6}$ See Rodrik, 1992, for a first attempt to formalize this. Using a highly stylized model of interaction between the government and the private sector, I show that, compared to a strong state (the Stackelberg leader), a weak state (a Stackelberg follower) systematically underprovides economically desirable interventions, and systematically overprovides politically motivated (and economicaliy harmful) interventions.

'As Migdal puts it, "[a]11 these cases [Israel, Cuba, China, Japan, Vietnam, Taiwan, North Korea, and South Korea] of relatively strong states have occurred in societies in which major social disturbances rocked existing structures within the last half-century" (1988, 269). 
I will expand on these points in the following sections. Export subsidization is a good area to try some of these ideas out for a number of reasons. For one thing, it is the policy on which the strategic trade policy literature has focussed. Second, it is very common: most countries have tried it at some time or another, and this provides a large sample. Third, the administration of export subsidies tends to be "organizationally demanding" (Levy, 1993, 257), opening a window into contrasts in state capabilities. Finally, the received wisdom on export subsidies is that they have not been effective (Nogués, 1990, and Thomas and Nash, 1991b).

\section{Two Successful Cases: Korea and Brazil}

A. KOREA

Korea's phenomenal export boom starting in the early 1960 s is well known. Less well known is the significant role played by the korean government's micro-management of export incentives in producing the boom. It is not a great exaggeration to say that the manner in which the Korean bureaucracy administered and coordinated the export push of the 1960 s and 1970 s is reminiscent of the way that the military command of a nation would run a war.

Under the Rhee government of the 1950s, Korean policy was preoccupied by largely political considerations, and the government attached no particular importance to either economic growth or exports (Jones and Sakong, 1980, 272-273). While there were some export subsidies, they were implemented haphazardly, and often not budgeted at all (Frank et al., 1975, 38-39). This changed dramatically after Park took over in a military coup on May 16, 1961. Park made exports his top priority, and aside from devaluing the won, greatly expanded 
the scope of export subsidization. Table 1 shows estimates of the combined ad-valorem equivalents of export subsidies during 1958-70. Two significant jumps in the subsidies are evident from the data, one in 1961-62 and another one in 1966-67.

\begin{tabular}{|r|c|c|c|c|r|}
\hline \multicolumn{6}{|c|}{ Table 1: Export Subsidies in Korea, 1958-70 (8) } \\
\hline \hline & $\begin{array}{c}\text { direct } \\
\text { subsidies }\end{array}$ & $\begin{array}{c}\text { tax } \\
\text { exemptions }\end{array}$ & $\begin{array}{c}\text { duty } \\
\text { exemptions }\end{array}$ & $\begin{array}{c}\text { credit } \\
\text { subsidies }\end{array}$ & Tota1 \\
\hline 1958 & 0.00 & 0.00 & 0.00 & 2.30 & 2.30 \\
\hline 1959 & 0.00 & 0.00 & 0.00 & 2.53 & 2.53 \\
\hline 1960 & 0.00 & 0.00 & 0.00 & 1.85 & 1.85 \\
\hline 1961 & 5.89 & 0.00 & 0.00 & 0.75 & 6.64 \\
\hline 1962 & 7.94 & 4.35 & 3.58 & 0.66 & 16.54 \\
\hline 1963 & 3.14 & 4.67 & 5.06 & 2.20 & 15.07 \\
\hline 1964 & 1.36 & 3.86 & 4.66 & 2.80 & 12.68 \\
\hline 1965 & 0.00 & 6.11 & 5.79 & 2.86 & 14.76 \\
\hline 1966 & 0.00 & 7.54 & 7.85 & 3.79 & 19.18 \\
\hline 1967 & 0.00 & 8.52 & 9.07 & 5.45 & 23.04 \\
\hline 1968 & 0.00 & 8.27 & 14.32 & 5.50 & 28.10 \\
\hline 1969 & 0.00 & 9.07 & 11.89 & 5.11 & 26.06 \\
\hline 1970 & 0.00 & 9.61 & 12.66 & 5.57 & 27.84 \\
\hline
\end{tabular}

Source: Calculated from Frank et al., 1975, Table 5-8.

Exporters had access to a bewildering array of subsidies in this period. Direct cash grants were important very early on, but were phased out by 1965, and replaced by tax and import duty exemptions. In that year, the priority given to exporters in acquiring import licenses was formalized and expanded: exporters were allowed duty-free imports of raw materials and intermediate inputs up to a limit. This limit was determined administratively, on the basis of firms' and industries' input-output coefficients plus a margin of "wastage allowance". Since the imports acquired under the wastage allowance could be sold in the domestic market, this was a significant subsidy and was consciously used as such. Frank et al. (1975, 66) estimate 
that the wastage allowance alone provided an export subsidy of 4.6 percent in 1968 on average, and up to 17-21 percent in certain fabrics and footwear. Bureaucrats had virtually unrestricted discretion in setting wastage allowances, and their generosity varied from time to time (Frank et al., 50). Businesses and trade associations regularly lobbied for increased allowances.

Subsidized credit to exporters was another significant incentive. As Table 1 shows, it became particularly important after 1966. Frank et al. (1975, Table 5-5) list twelve different types of preferential loans to exporters that were operative in the 1967-1970 period.

A noteworthy feature of the Korean export subsidies is that they applied not only to the final exporters, but to the indirect exporters as well (i.e., the firms that supplied the intermediate inputs used in exportables). The available econometric evidence indicates that exports were highly sensitive to subsidies: Jung and Lee (1986) estimate that a 1 percent increase in export subsidies eventually led to more than a 2 percent increase in export supply. Intriguingly, they also find that the elasticity of export supply with respect to the real exchange rate was smaller than this.

These subsidies were disbursed against a background of highly unusual government-business relationship. One of the first acts of the Park regime was to arrest most of the country's leading businessmen and to threaten the confiscation of their assets under a recently passed Law for Dealing with Illicit Wealth Accumulation (Jones and Sakong, 1980, 69) ${ }^{\ominus}$. A compromise was then arranged by which these businessmen would build factories and turn their shares over to

This law was actually passed by the short-lived Chang Myon regime intervening between the Rhee and Park years, but its implementation took place under Park's government. 
the government in exchange for their release. The matter was eventually closed in December 1964 with most businessmen paying their fines in cash (with fines amounting to a total sum of \$16 million). The planned transfer of ownership never took place. "Nonetheless," as Jones and Sakong remark $(1980,70)$, "the basic pattern was set, with businessmen in a decidedly subordinate role" to the state.

The ability of the government to elicit the desired response from firms by a combination of cajoling, arm-twisting, and threats was characteristic of the manner in which the export subsidies were administered. Westphal's description of the situation is worth quoting at length:

[T] he [Korean] government has not relied solely on market forces acting in response to incentives. It has also used publicly announced, quarterly export targets for individual commodities, markets, and firms. Contact between government and business in the day-to-day implementation of these targets has been close. Next to the responsible minister's of fice, an "export situation room" was established, laid out so that potential export shortfalls could be identified at a glance. A large staff has maintained almost daily contact with major exporters, and it has not been uncommon for the minister to intervene in difficult situations; for example, to obtain immediate customs clearence for inputs being delayed on some pretext. Progress towards targets and the current trade situation have been regularly reviewed at a Monthly Trade Promotion Conference, chaired by the president and attended by ministers, bankers, and the more successful exporters, large and small.

The highest export achievements have brought national awards as well as material benefits bestowed through discretionary means ... [including] additional preferences in the general allocation of credit under a system of government directed bank lending and relaxed tax surveiliance under a revenue system that gives government officials considerable latitude in determining tax liabilities.... Conversely, indolence has been deterred by the perception that discretion could be--indeed, sometimes was-exercised in ways that impose material costs or deny potential benefits in other areas of a firm's activity. (Westphal, 1990, 45-46.)

There was clear understanding on the part of firms that good export performance would be rewarded by various kinds of government benefits, while poor performance would bring forth penalties. Most notable 
among the penalties were tax inspection and collection applied more rigorously than usual (Rhee et al., 1984, 92).

As the passage quoted above makes clear, the government issued specific export targets for firms las well as commodities and export markets). When the government first began to issue such targets, the heads of firms are reported to have willingly complied, "with the[ir] memory still fresh of their being jailed by the new regime for the illicit accummulation of wealth" (Rhee et al., 1984, 21). Eventually, firms began to set their own targets, but remained constrained by past performance as well as the vigilance of bureaucrats in extracting maximum export performance. ${ }^{9,10}$

The extent to which the government's priorities and resources were organized around export performance is striking. As mentioned in the passage by Westphal above, the monthly trade promotion conferences were chaired by President Park himself, and he often took decisions on the spot. Exports were monitored literally on a daily basis:

The head of the export promotion office in the Ministry of Commerce and Industry has at his side a computer printout of progress against targets by industry and by firms. The data is for the preceding day, which is all the more remarkable when it is considered that most developing countries do not have aggregate information on exports for many months. The printout is also broken down by geographic region. If sales in a region

${ }^{9}$ Around half or more of the firms surveyed by Rhee et al. (1984) reported that the export targets had negative effects on the firm in terms of profitability or sales diversion. Enterprise-level export targets have also been used, apparently quite successfully, in China (see Panagariya, 1993).

${ }^{10}$ As it turned out, most firms regularly exceeded their targets. Balassa (1978) reads this as evidence that targets did not play an important role. However, that fact itself says nothing about how binding these requirements were ex ante: for one thing, Korean exports grew at a stupendous rate that would have been impossible to predict beforehand; secondly, there was a general expectation that failure to meet targets would attract penalties, creating strong incentives for fulfillment; third, over-fulfillment brought rewards from the administration. 
are not up to target, the Korean ambasadors there are recalled to find out what the problems are and what can be done to spur

Korean sales. And in the foyer of the head office of the Korean Traders' Association is a big board tracking the progress of each industry towards its target. The export associations of each industry, the nodes for all information flows on exports, have their own boards tracking progress. So do firms on the shop floors, where workers--dressed in uniforms that give all of industry a paramilitary air--keep track of their firm's progress toward targets and of that by competitors down the street. (Rhee et al., 1984, 22)

The extreme discretion that trade officials had allowed them to be flexible and respond quickly to changes in circumstances. For example, export targets for automotive products were scaled down more than once during the 1970s (Westphal, 1990, 54), and a survey by Rhee et al. (1984) found that nearly a third of the respondents had their targets revised during 1973-75.11 But when asked whether a firm had any say in setting the export target for itself, 47 of the 97 firms replied negatively.

Without these two institutional innovations--the practice of setting and monitoring export targets and the holding of monthly trade promotion conferences--the export incentives themselves would arguably not have been as effective (Rhee et al., 1984). These were instrumental in communicating the top leadership's priorities to lower level bureaucrats and to firms alike, in resolving administrative problems quickly, and as a combined carrot-and-stick strategy more

"Here is how Jones and Sakong $(1980,61)$ describe the down side of the discretionary environment: "Businessmen often complain about the sudden shifts in policy direction, and (at a decidedly lower level of importancel academics are regularly frustrated when their critiques of policy become outdated before reaching print." But according to Rhee et al. (1984, 36): "Eirms ... saw the flexibility and frequent adjustments in the incentive system not as characteristics that would create uncertainty about the automaticity and stability of that system. They saw them as part of the government's long-term comitment to keep exports profitable...." 


\section{6}

broadly. To the question of why firms did not systematically manipulate the incentives or set low targets (as in socialist economies), the simple answer is that state officials were on top of things. In turn, low-level corruption on the part of bureaucrats themselves was ruled out by the high priority given to the export drive by the top leadership.

The Korean state's strength (or autonomy) is usually ascribed to a number of distinctive circumstances. According to Amsden (1989, $54), "[t]$ he Korean state was able to consolidate its power in the 1960 s because of the weakness of the social classes. Workers were a small percentage of the population, capitalists were dependent on state largesse, the aristocracy was dissolved by land reform, and the peasantry was atomized into smallholders." Others like Evans (1992) also stress the importance of a tradition of meritocratic bureaucracy. Such historical consideration, however, do not explain how the Korean state under Park was able to metamorphose itself from its poor cousin under Rhee. ${ }^{12}$ We also need to take into account the coherence of export policies under Park--the consistent priority given to them at the expense of other objectives--and the lack thereof under Rhee.

\section{B. BRAZIL}

Brazil's economy has been so mismanaged since the early 1980 s that it is hard to imagine the presence there of an effective program of export subsidies. Yet starting in the second half of the $1960 \mathrm{~s}$ an extensive set of export incentives was successfully implemented and

${ }^{12}$ Survey results reported in Jones and Sakong (1980, Table 22) show a striking difference in firms' perceptions with regard to the effectiveness and hardness of economic policies under the two regimes. 
led--alongside a crawling exchange rate policy--to an impressive increase in manufactured exports. It was this export performance that prompted many observers to talk about a "Brazilian miracle," until the debt crisis of 1982 and macroeconomic mismanagement turned the economy into a big mess.

Prior to the military coup of 1964, government policy in Brazil did not attach particular attention to exports, in keeping with the bias towards import-substitution. The incoming government, like Park's regime, developed a clear commitment to exports. There was some liberalization of import restrictions, a move (in 1968) to a crawling peg regime to maintain competitiveness, and the development of an extensive and generous system of export subsidies for

\begin{tabular}{|l|c|c|c|c|c|r|}
\hline \multicolumn{7}{|c|}{ Table 2: Export subsidies in Brazil, 1969-1985 (8) } \\
\hline \hline & $\begin{array}{c}\text { Duty } \\
\text { drawback }\end{array}$ & BEFIEX & $\begin{array}{c}\text { Tax credit } \\
\text { premium }\end{array}$ & $\begin{array}{c}\text { credit } \\
\text { subsidies }\end{array}$ & $\begin{array}{c}\text { Income } \\
\text { tax } \\
\text { exempt. }\end{array}$ & Total \\
\hline 1969 & 4.0 & -- & 6.7 & 4.1 & 0.0 & 14.8 \\
\hline 1970 & 4.0 & -- & 13.5 & 7.5 & 0.0 & 25.0 \\
\hline 1971 & 4.0 & -- & 13.2 & 7.8 & 1.3 & 26.3 \\
\hline 1972 & 4.9 & n.a. & 16.3 & 8.2 & 1.3 & 30.7 \\
\hline 1973 & 7.2 & n.a. & 16.2 & 6.5 & 1.3 & 31.2 \\
\hline 1974 & 12.6 & n.a. & 12.0 & 6.1 & 1.8 & 32.5 \\
\hline 1975 & 8.3 & n.a. & 12.1 & 11.5 & 1.7 & 33.6 \\
\hline 1976 & 11.8 & 3.6 & 11.7 & 15.9 & 1.3 & 44.3 \\
\hline 1977 & 12.6 & 4.6 & 12.4 & 19.6 & 1.5 & 50.7 \\
\hline 1978 & 9.1 & 5.0 & 12.8 & 17.0 & 1.8 & 45.7 \\
\hline 1979 & 10.5 & 5.4 & 12.8 & 13.9 & 2.1 & 44.7 \\
\hline 1980 & 9.0 & 8.1 & 0.0 & 2.0 & 1.9 & 21.0 \\
\hline 1981 & 9.4 & 10.2 & 6.5 & 18.7 & 1.8 & 46.6 \\
\hline 1982 & 10.3 & 7.7 & 9.1 & 21.7 & 1.6 & 50.4 \\
\hline 1983 & 8.6 & 4.9 & 7.8 & 9.3 & 1.6 & 32.2 \\
\hline 1984 & 9.1 & 4.3 & 7.8 & 2.7 & 1.6 & 25.5 \\
\hline 1985 & 9.1 & 5.9 & 1.4 & 3.6 & 1.6 & 21.6 \\
\hline
\end{tabular}

Source: Clements (1988), pp. 15-17, and GATT (1992), Table IV.14-15. 
manufactures. These subsidies included duty and tax rebates, income tax exemption, credit subsidies, and many others (see Table 2). By the latter half of the 1970s, the combined value of these subsidies stood close to 50 percent of exports. As in Korea, these subsidy programs were implemented in a highly selective and discriminatory manner. ${ }^{13}$ Export subsidization varied greatly from industry to industry, as well as from firm to firm. Almost without exception, the larger firms obtained a disproportionate share of the subsidies (Easano-Filho et al., 1987, 66).

The effectiveness of these subsidies appears beyond question. In a survey of export subsidies in Latin America, Nogués (1990) lists only the Brazilian case as a success. Fasano-filho et al. (1987) provide econometric evidence of their importance in export supply decisions. A World Bank study $(1983,121)$ credits the BEFIEX program (discussed below) for stimulating a significant amount of new investments oriented towards world markets. Perhaps most telling of all is that Brazilian manufactured exports expanded at an annual average rate of 38 percent during the $1970 \mathrm{~s}$.

Among the subsidies listed in Table 2, one stands out in terms of effectiveness and distinctiveness. This is the BEFIEX program, introduced in 1972. (BEFIEX is the Brazilian acronym for Fiscal Benefits for Special Export Programmes.). According to Fritsch and Franco (1992, 9), this was the most important of the export subsidies. The scheme was unusual in that it entailed the signing of long-term contracts (for usually 10 years) by participating firms detailing their export commitments. Aside from these export commitments, firms

${ }^{13}$ Evans (1979, 93-94) characterizes post-1964 Brazil as "a case of espousing liberal free enterprise while acting to increase vastly the econornic role of the state, both regulatory and entrepreneurial." 
also had to satisfy minimum local-content requirements in order to qualify for BEFIEX incentives. The contracts were negotiated with the BEFIEX administration on the basis of detailed information on firms' activities and strategic plans. The incentives, in turn, typically included "90\% reduction of import duties and the Industrialized Products $\mathrm{Tax}$ (IRI) on imported machinery and equipment; $50 z$ reduction on import duties and IPI tax on imported raw materials, parts and components, and other intermediate products; exemption from the 'similarity' test; and income tax exemption on profits attributable to exports of manufactured products" (GATT, 1992, 104).14

Between 1972-1985, 316 contracts were signed, mainly with multinational enterprises in the transport equipment and textile and

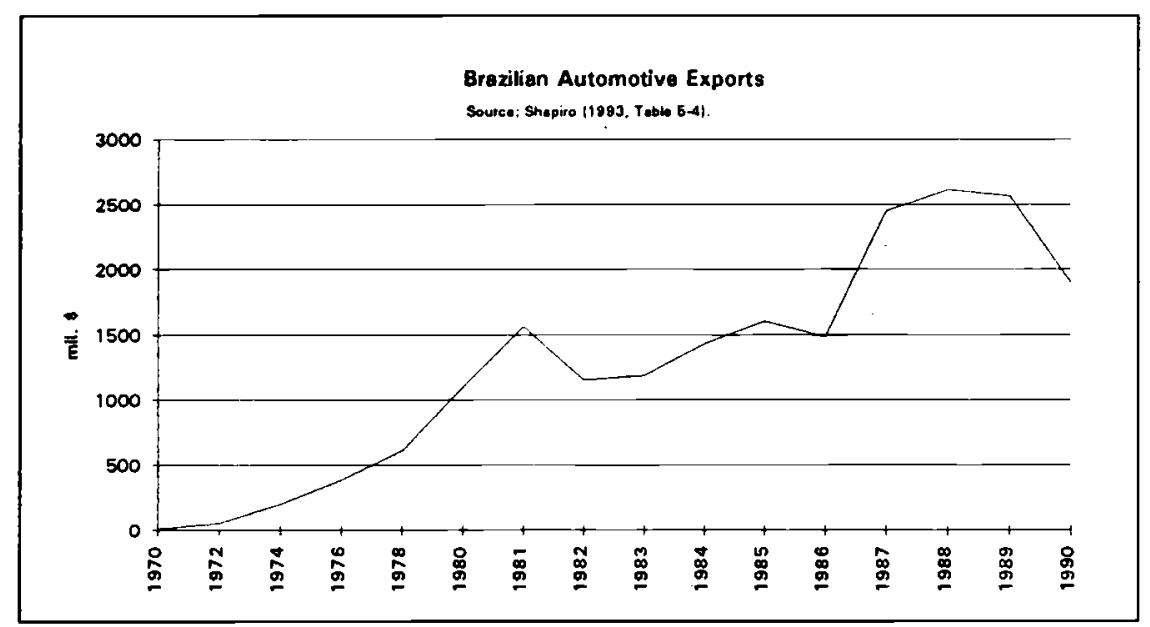

Figure 1

${ }^{1 " T h e ~ " s i m i l a r i t y ~ t e s t " ~ i n ~ t h e ~ q u o t e ~ r e f e r s ~ t o ~ t h e ~ i n f a m o u s ~ l a w ~}$ that prohibited the importation of foreign products when similar products were available domestically. 
clothing industries. In the automotive sector, GM, Ford, and VW each committed to $\$ 1$ billion of exports over ten years, Fiat to $\$ 550$ million, and Mercedes Benz to $\$ 500$ million (Shapiro, 1993, 213; World Bank, 1983, 257). The effect of the program in this sector was nothing short of dramatic. As shown in Figure 1, automotive exports rose from virtually nothing in 1972 to more than $\$ 1$ billion in 1980 . Total exports under BEFIEX contracts increased to $\$ 8.2$ billion by 1990, at which time the program was phased out as part of an overall trade liberalization. According to a GATT study (1992, 104), EEFIEXlinked exports eventually covered about half of all manufactured exports.

To an economist, perhaps the most striking thing about BEFIEX is the apparent absence of gaming between firms and the government and of renegotiation of initial contract terms. Participation in BEFIEX meant that firms were under legal obligation to live up to their export commitments, irrespective of economic circumstances such as foreign demand conditions or exchange-rate fluctuations. These were tough terms, and firms apparently lived by them. In her study of the Brazilian automotive industry, Shapiro (1993) mentions instances in which multinationals had to make adjustments to their global strategies--by cutting back exports from third countries, for example-so as not to run afoul of BEFIEX export commitments. ${ }^{15}$ This must be confounding to economists who generally believe that long-term

15 In the late 1980s, GM headquarters allowed the Brazilian subsidiary to export engines to GM-Opel (Germany) for the first time, even though the firm's global strategy had assigned the European market to its Australian subsidiary. "GM was forced to grant Brazil access to the European market... [because otherwise] GMB [GM-Brazil] would not have been able to meet its export commitments..." (Shapiro, 1993, 222). Fiat began to export the Uno from Brazil, even though it would not have done so without BEFIEX (ibid., 223). 
contracts are not enforcable, especially when the government is on one side, and must come under severe renegotiation pressure in response to unforeseen circumstances. In this instance the Brazilian state had the capacity to discipline firms, and was perceived as such. It is difficult to envisage this kind of discipline being exerted in the countries that we will turn to next. ${ }^{16}$

Just as in the Korean case, the reasons for the Brazilian state's strength and autonomy in the area of export policy remain murky. Leff argues in his study of economic policy making during the earlier 194764 period that the Brazilian government could always act autonomously from special interest groups, and impose policy rather freely (Leff, 1968). His description of Brazil is reminiscent of Jones and Sakong's (1980) Korea. On pre-1964 export policy, he writes: "policy here was made in direct opposition to the interests of major private groups, the exporters and the landed elites producing primary products, in deference instead to doctrines which commanded widespread influence among the government administrators and in elite opinion" (Leff, 1968, 77). ${ }^{17}$ He lists several reasons for the state's autonomy, and notes in particular the emergence of a strong government prior to the development of manufacturing interests.

Evans (1992) presents a rather different picture of the Brazilian state, much less autonomous, and having to contend with important

\footnotetext{
${ }^{16}$ Indeed, in Turkey's case export commitments were formally demanded, but remained on paper.

${ }^{17}$ Hence, Leff leaves no doubt that autonomy did not come with the military coup--it existed prior to 1964. This is important because it suggests that authoritarianism need not be a pre-condition for autonomy. Jones and Sakong also express doubt about the relationship between authoritarianism and autonomy in the case of Korea: "Until the early 1970s, the Park regime was both hard and reasonably democratic" $(1980,140)$.
} 
social groups. Evans notes that clientelism was rampant, that the bureaucracy had (compared to Korea, for example) much less of a tradition of meritocracy, and that there was no policy coordination within the state. "Even the military regime, which had the greatest structural potential for insulation from clientelistic pressures, proved unable to construct an administrative guidance relationship with the local industrial elite" (Evans, 1992, 170). However, he notes the presence of "important pockets of state efficiency", mentioning in particular the state's relationship with the auto sector. The co-existence of pockets of autonomy with general state weakness rings true in light of the macroeconomic crisis in which the Brazilian state--virtually alone in Latin America--still remains deeply mired. It suggests the possibility that state strength may vary not only across time but also across sectors and issues.

\section{Two Failures: Kenya and Bolivia}

\section{A. Kenya}

Kenya's export subsidization policy is undistinguished in many respects, including effectiveness. The only thing that recommends it to our attention is the presence of a good study by Patrick Low (1982), who observed it at close distance.

Compared to the Korean and Brazilian programs we have just discussed, the Kenyan scheme was on paper an economist's dream: it could not have been simpler, less discretionary, nor more uniform. The Local Manufactures (Export Compensation) Act of 1974 applied a straightforward 10 percent export subsidy to most manufactures. (The rate was increased to 20 percent in 1980.) The only restriction was that the value of imported goods could not amount to more than 70 
percent of the value of the export. The subsidy was to be paid through commercial banks, after export proceeds were received and after government officials processed the subsidy claims.

The effects of the program were imperceptible. Low (1982) interviewed 55 firms and found that only 16 (29 percent) of them had responded by increasing exported output. The plurality of firms 117 , or 31 percent) treated the subsidy simply as a windfall, while 7 firms (13 percent) did not even bother to claim the subsidy. Even more telling is Low's calculation that at the aggregate level less than 30 percent of eligible exports actually received the subsidy. A very large number of exporters either did not claim the subsidy or did not get it.

What seems to have happened is a bit of both. Government officials processing the subsidy claims exercised such zeal that many applications were rejected on trivial grounds. Low spent a day with these officials and observed two claims being rejected, "one because a date had been inadvertently omitted on a form and the other because the quadruplicate instead of the sextuplicate copy of the Export Entry form had been submitted with the claim" $(1982,297)$. The officials also took their time. More than a quarter of the firms interviewed by Low expected to wait more than six months after claims had been filed. And since the claims could not be filed before export proceeds were actually received, the total waiting time was even longer than this. The delay and unpredictability explain why many firms did not bother to claim, and why those that did treated the subsidy as a lump-sum payment, not to influence their export decisions.

At a deeper level, the failure of this program must be attributed to the fact that the Kenyan government never clearly sorted out and 
prioritized its objectives as they impinged on the export subsidy policy. While encouraging exports for more correctly reducing the anti-export bias due to import restrictions) was obviously an objective, it did not rank very high in the overall scheme of things. Neither was the apparent conflict with the negative fiscal implications of the program ever resolved. Note that the program was administered by the Customs and Excise Department, a revenue-raising body. Since providing the subsidy was expensive, the program as it stood was subject to a clear time inconsistency: the dynamically consistent policy was to promise to pay the subsidy but not to do so (since payment was to occur after exports had gone out). There was no commitment to exports on the part of the top leadership (as in Korea or Brazil) that would help resolve this dilemma on the side of exports.

In partial recognition of these problems, the government reformed the program in 1980. The subsidy was raised to 20 percent, coverage of the scheme was expanded to almost all non-traditional exports, and an attempt was made to streamline administrative procedures. Two features of the reform deserve special mention. First, the increase in the subsidy was accompanied by an equivalent 10 percent surcharge on imports. This was intended to de-emphasize fiscal considerations in the implementation of the subsidy, but is also indicative of the incoherence of policy: by the Lerner symmetry theorem, the import surcharge served to cancel the effect of the increase in the export subsidy. ${ }^{1 \theta}$ Second, administrative responsibility for the subsidy scheme was moved from the Customs and Excise Department to the Central

\footnotetext{
${ }^{18}$ Almost. The equivalence was not exact, of course, because there were prevailing tariffs that were generally higher than the preexisting $10 \%$ export subsidy.
} 
Bank, an institution with less stake in revenue and greater reputation for bureaucratic efficiency.

Low's study does not extend to the period after 1980, so we do not have a good account of how these reforms fared. There is reason to be skeptical however. A recent account in The Economist (August 14, 1993, 37-38) relates the scandalous story of a Kenyan firm called Goldenberg. This firm, the sole recipient of a license to export gold and jewellery, apparently received $\$ 54$ million in export subsidies from the Central Bank (amounting to 5 percent of Kenya's total exports!). Not only was the firm paid a subsidy of 35 percent (rather than 20 percent, as the law requires), but the foreign firms to which Goldenberg claimed to have shipped its exports were either fictituous or had never heard of Goldenberg. Kenya's export policy has apparently moved from the Scylla of incentive-blunting diligence to the Charybdes of corrupt generosity.

\section{B. BOLIVIA}

Between 1987 and 1991, Bolivia had an export subsidy program similar to the Kenyan scheme, which also failed for virtually identical reasons. As the authorities never resolved the conflicting objectives of safeguarding revenue versus stimulating exports, the exporters reacted by alternatively ignoring the scheme and badly abusing it.

The export subsidy introduced in July 1987 was in principle aimed at reimbursing exports for duties paid in imported inputs (hence the acronym CRA, standing for the initials for Tariff Refund Certificate in Spanish). However, rather than create an explicit drawback scheme which can be an administrative nightmare, the government sensibly set the subsidy at a uniform 10 percent for non-traditional exports and 5 
percent for traditional exports. (The top rate was subsequently lowered to 6 percent in August 1990, following a tariff reduction.)

Bolivia had recently come out of a hyperinflation, with inflation running at more than 40,000 percent per annum and a budget deficit of more than 20 percent of GDP prior to the stabilization of August 1985. The authorities were naturally more than slightly nervous about the budgetary implications of the subsidy. Partly for that reason, the entry into force of the CRA was delayed. No CRA certificates were issued before April 1988, and a new regulation in september 1988 retroactively limited the benefits accruing to some of the exporters having earned CRA rights between July 1987 and April 1988.

Apparently, no CRA payments were made until 1989 (see GATT, 1993, Table IV.8). And once payments began to be made, enterprising individuals and firms freely abused the system: there was a famous case of so-called tourist cows (vacas turistas) in which cow herds were led across the Bolivian borders several times, collecting CRA benefits at each crossing (GATT, 1993, 93). The system was finally scrapped in April 1991, and replaced by a narrower scheme with lower financial benefits.

Hence we have once more a clear example of a uniform, transparent scheme which fails because: (i) delays in payments blunts incentive effects early on; and (ii) when payments are made, fraudulent practices take over and cannot be reined in. The government is then forced to narrow the scope of a scheme which has a large fiscal impact but little incentive effect. ${ }^{19}$

\footnotetext{
${ }^{19}$ This combination of delays with fraudulent response is apparently quite general. Additional cases appeared in Senegal and Côte d'Ivoire during the second half of the 1980s, when the governments in both cases decided to undertake a simulated devaluation by increasing import tariffs and export subsidies simultaneously.
} 


\section{Two Intermediate Cases: Turkey and India}

\section{A. TURKEY}

Turkish economic policy experienced a radical shift to export orientation as a result of a dramatic package of measures undertaken in January 1980 by Turgut özal (then a top technocrat, and subsequently prime minister and president). Undertaken in the midst of a macroeconomic crisis, the package included a devaluation, fiscal actions, and a series of measures designed to enhance export incentives. Alongside a flexible exchange-rate policy, the generous package of export subsidies did much to contribute to the export boom that ensued (see Arslan and van Wijnbergen, 1990, and Uygur, 1993, for econometric evidence linking subsidies to export supply). However, it also led to much abuse and a phenomenon that came to be called "fictitious exports"--various forms of fraud designed to take advantage of the financial incentives.

These subsidies were of many types. They comprised export tax rebates (supposedly to compensate for indirect taxes, but going well beyond them), sub-market export credits, foreign exchange allocations which conferred the right to duty-free imports, corporate tax reductions (after 1981), and additional tax rebates for enterprises exporting above a threshold (Milanović, 1986; Krueger and Aktan, 1992; Togan, 1993). The combined ad-valorem equivalent of these subsidies rose to 34 percent in 1983, coming down thereafter to around 26 percent (see Table 3). Exports were a top priority for Özal, to the point where "the success of the export drive became almost synonymous with the success of the stabilization program" (Milanovic, 1986, 73). He took pains to ensure that no obstacle stood between an exporter and 


\begin{tabular}{|l|c|c|c|c|c|c|}
\hline \multicolumn{2}{|c|}{ Table 3: Export Subsidies on Manufactures in Turkey, 1980-86 (8) } \\
\hline & $\begin{array}{l}\text { Tax } \\
\text { rebates }\end{array}$ & $\begin{array}{l}\text { Export } \\
\text { credits }\end{array}$ & $\begin{array}{l}\text { Foreign } \\
\text { exch. } \\
\text { retent. } \\
\text { alloc. }\end{array}$ & $\begin{array}{l}\text { VAT } \\
\text { exempt. }\end{array}$ & Others & Total \\
\hline 1980 & 5.9 & 5.5 & 5.8 & -- & 0.0 & 17.2 \\
\hline 1981 & 3.6 & 6.4 & 4.9 & -- & 4.0 & 15.3 \\
\hline 1982 & 9.5 & 7.2 & 6.7 & -- & 6.0 & 24.0 \\
\hline 1983 & 11.8 & 7.9 & 13.0 & -- & 1.5 & 34.2 \\
\hline 1984 & 11.3 & 6.0 & 4.0 & -- & 2.0 & 23.3 \\
\hline 1985 & 3.1 & 3.2 & 3.9 & 10.0 & 5.8 & 26.0 \\
\hline 1986 & 1.9 & 3.6 & 6.5 & 10.2 & 4.6 & 26.8 \\
\hline Source: Krueger and Aktan $(1992)$, Table 14 & & \\
\hline
\end{tabular}

his claim to a subsidy. One of his key institutional innovations was the centralization of export incentives, which had been previously dispersed among numerous government agencies, in a specific agency, the Directorate of Incentives and Implementation (TUD) within the State Planning Organization. Exporters now had to apply to the TUD to obtain an "export investment certificate", which served as the basis for receiving all the subsidies discussed above. This stood in stark contrast with previous practice whereby an exporter would have to establish his standing with each agency separately. The new system was simple and rapid, and exporters could get their certificates within weeks or days (Krueger and Aktan, 1992, 76). ${ }^{20}$

Obtaining the export certificate entailed the undertaking of a quantitative export commitment on whose realization the granting of incentives in principle depended (Milanović, 1986, 6). In practice,

${ }^{20}$ There were occasional glitches though. In 1983 and 1984 shortage of government funds led to important arrears in both tax refunds due to exporters and interest rate rebates for export credits due to commercial banks (Milanovic, 1986, 48). 
this was a commitment that the government easily waived. According to Krueger and Aktan (1992, 247, fn 5): "If, for some reason, the export was not realized, [the firms] simply notified TUD/TUB that they would not be exporting that amount, and there was no penalty." Eirms believed that the authorities would impose penalties only in cases where the certificate had been obtained with no intent to export at all (ibid.).

As mentioned above, these subsidies led to widespread abuse. Documented cases included instances in which: (i) low-value items such as scrap metal or stones were exported under the guise of industrial products with high tax-rebate rates; (ii) low- or medium-grade items (such as common rugs) were over-invoiced as high-grade (silk rugs); (iii) the quantity shipped was overstated, as in the case of leather wallets whose number was blown up by a factor of $100^{21}$; and (iv) the most egregious of all, entire export operations took place on paper only, with no physical transaction ever taking place (these and other cases are detailed in a popular book by Cetin, 1988).

An attempt to quantify the extent of over-invoicing and other mischief that took place is shown in Figure 2. These estimates are based on comparisons of Turkish export statistics with OECD statistics for imports from Turkey. The presence of over-invoicing is unmistakable. Until 1981, the calculations reveal a small underinvoicing, which is not surprising in view of the black-market premium for foreign currency that existed prior to the 1980 stabilization. But over the course of the first half of the 1980s, over-invoicing increased steadily, reaching more than 25 percent of export value by

\footnotetext{
${ }^{21}$ This case came to light because the exporting firm had neglected to raise the weight of the shipment by the same factor, leading to ridiculously low unit weights (cetin, 1988, 34).
} 


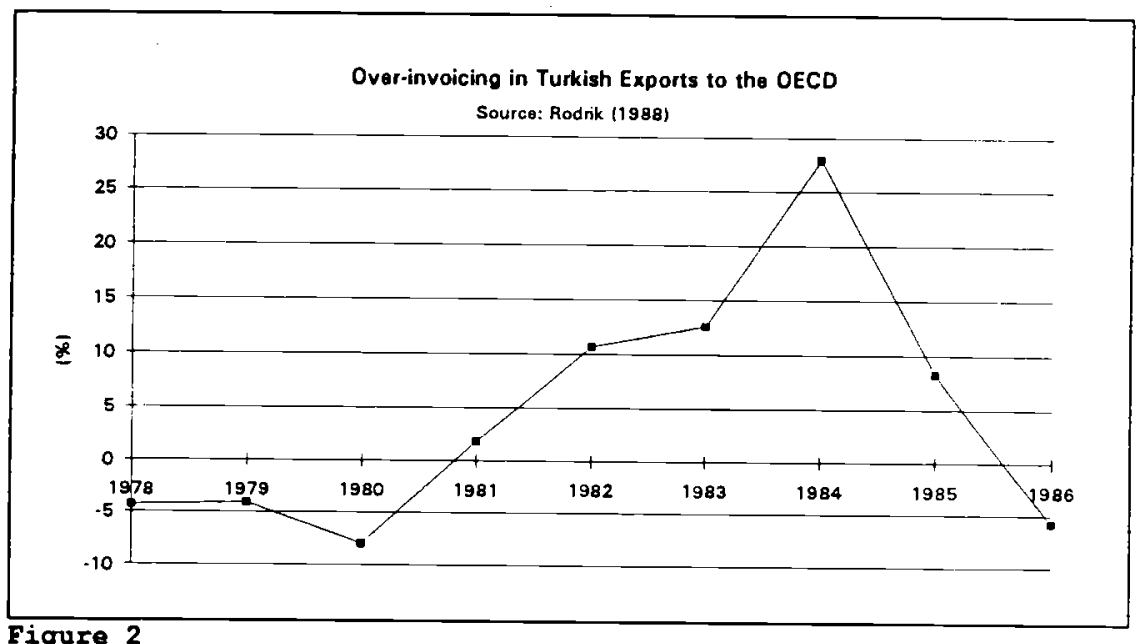

1984. It thereafter decreased sharply, partly because of the decline in subsidies and partly because "fictitious exports" became a hot political issue and became risky for all but the most adventurous of firms. It should be mentioned, however, that the Turkish export boom of the $1980 \mathrm{~s}$ looks only slightly less impressive when over-invoicing is taken into account. In other words, the boom was not a statistical illusion by any stretch of the imagination.

Özal, who was a brilliant technocrat, was fully aware of the abuses that the subsidies were giving rise to. State officials had large numbers of files on suspected abuses. But özal firmly resisted the Turkish bureaucracy's inclination to tighten the regulations and prosecute the fraudulent cases (Cetin, 1988). He feared that unleashing the bureaucracy on exporters would do more harm than good, and discourage the legitimate exporter alongside the fictitious one. Put differently, unlike in the Korean and Brazilian cases, the Turkish 
bureaucracy could not be trusted to find the right balance between providing incentives and discouraging potential abusers. He thus understood very well the dilemma of a weak state: the carrot and the stick may not be available simultaneously, so one has to go with one or the other. A corollary is what we may call the second-best law for weak states: a weak state may become less effective in trying to act strong.

\section{B. INDIA}

Until very recently, India was hardly known for its pro-export policies. Export subsidies of one kind or another have always been part of the Indian policy landscape, but these were greatly overshadowed by a highly restrictive import regime. Here I will focus on the period before the devaluation of 1966, on which we have the excellent and enormously detailed study by Bhagwati and Desai (1970). This is a case of mixed success, somewhat like Turkey's except less stark. The subsidies in place appear to have played a role in stimulating exports, but they also led to fraud.

Indian exporters had already access to a variety of fiscal subsidies during the late 1950s, but these were considerably strengthened in the course of the early 1960s. The most significant subsidy, on which I will concentrate, was an import entitlement scheme under which exporters were awarded import licenses in proportion to the value of their exports. According to Bhagwati and Desai (1970, 406), the average premium for import licenses were of the order of $70-$ 80 percent, so the incentive effect of this policy can be easily imagined.

Bhagwati and Desai characterize Indian state administration in 
the trade policy area as "ad hocism at the top and corruption at the bottom" (1970, 134). Yet the import entitlement scheme started out as a relatively non-discretionary program with well-defined rules. Two principles were laid down at the outset to govern the scheme's administration: (i) import entitlements would not exceed 75 percent of the f.o.b. value of exports; and (ii) subject to the previous constraint, the entitlement would equal only twice the value of an exporting firm's import content (ibid., 409). As it turned out, these rules were frequently flouted by the authorities who were anxious to demonstrate success on the export front. Note that since subsidies consisted of import licenses, they had no immediate fiscal impact (unlike in Bolivia and Kenya), and there was consequently little inherent resistance to awarding them. In turn, the officials were aided in this by exporters themselves who naturally lobbied for the most generous terms possible. As Bhagwati and Desai put it, the increasing subsidy "reflected the growing pressure to make exports more profitable, on the part of the exporters, combined with an accommodating Ministry whose objective was to maximize export earnings" (ibid., 426).

Given these pressures, the Indian export subsidy scheme eventually took on a perverse quality with subsidies awarded in inverse relationship to an exporter's competitiveness. That is, exporters could get a subsidy large enough to make their exports profitable by manipulating the government: "it became generally possible to ask the Ministry of International Trade for ad hoc entitlements, for chemical and engineering exports, to make up for any ostensible difference between the domestic sale price of a product and its supposed f.o.b. export price plus the subsidy normally available" 
(ibid., 465-66). Bhagwati and Desai also note that the scheme resulted in significant over-invoicing, as in Turkey. ${ }^{22}$

For all its problems, Bhagwati and Desai credit the export subsidies of the period as being "undoubtedly instrumental in sustaining the spurt in the Indian export performance during the Third Plan [April 1961-March 1966]" (ibid., 429).

\section{Concluding Remark=}

These stories reveal a wide variety of experience with export subsidies. Policies that look identical on the books often produce different results, and policies that appear ex ante well designed frequently result in failure. Perhaps the greatest surprise is that the most successful programs in our sample were the ones in which state officials exercised the greatest discretion, applied the least uniformity (at least ex ante), and interacted the most intensively with firms. The other cases, however, make clear that these successful experiences cannot easily be replicated in settings characterized by weak states. ${ }^{23}$

\footnotetext{
${ }^{22}$ They point out that partner-country trade statistics were not helpful to get a sense of the magnitude of over-invoicing in this case because the over-invoicing occurred with free ports like Aden, Hong Kong, and Panama.

${ }^{23}$ It is useful to interject here Hernando de Soto's poignant complaints about the unpredictability of policy-making in Peru: "It is simply untrue that, in Peru, we are all equal before the law, because no two people pay the same tax, no two imports are taxed in the same way, no two exports are subsidized in the same way, and no two individuals have the same right to credit.... Uncertainty is constant in the redistributive state, for the Peruvians are aware that the executive branch, which issues some 110 regulations and decisions each working day, can change the rules of the game at any moment without prior consultation or debate" (1989, 195-199). These complaints ring true to anyone who has observed policy making in developing countries. The trouble is that, absent the reference to the redistributive state, this statement is equally valid for Korean policy making. Jones and Sakong resolve the paradox in the following manner: "the lesson of the
} 
The message that comes out of the cases is both pessimistic and optimistic as regards state capabilities. On the one hand, the importance of state autonomy, which seems to be determined largely by historical and structural factors, underscores the point that the range of options open to most government may be fairly limited. On the other hand, policy coherence alone counts for something: weak states can achieve some of their objectives if their priorities are sufficiently crystallized and if they are creative in designing appropriate institutional frameworks. Centralizing subsidy functions in a high-visibility agency (as in Turkey) or processing claims through the trade ministry rather than the finance ministry (as in India) are examples of institutional considerations that may make a large difference in practice. ${ }^{24}$ Priorities are most clearly articulated and communicated when there exists political commitment on the part of the top leadership: in Korea, Brazil, Turkey, success derived in part from the clear, unmitigated commitment to exports by new regimes. The case of export subsidies shows that normally incoherent states can produce coherent policies when they attach a sufficiently high priority to them. On the other hand, nothing is

Korean case is that in a hard state with leadership commitment to growth, the Myrdalian objections to discretionary controls on economic grounds may be obviated. Just as compulsion is necessary, so also is discretion. Both mechanisms are potentially subject to great abuse, and their use constitutes a high-risk/high-gain strategy which is feasible only in a Myrdalian hard state" (1980, 139).

${ }^{24}$ Wade $(1990,371-77)$ offers some interesting ideas on how to improve state effectiveness through institutional engineering, not all of which however have tremendous operational content. His recommendations include to "establish a 'pilot agency' or 'economic general staff. within the central bureaucracy", to "develop effective institutions of political authority before the system is democratized" and to "develop corporatist institutions". 
more distinctive about weak states than a multiplicity of conflicting government objectives.

Some brief remarks on the U.S. case may be worthwhile at this point, because the feasibility of strategic export subsidization by the Federal government is an issue that arises frequently. The American political system is characterized by a strong form of division of powers, a set of overlapping jurisdictions and policy responsibilites, and the absence of an independent professional bureaucracy with a sense of tradition and continuity. These features render the American state a poor candidate for either autonomy or coherence. Richardson (1987, 267), for example, describes how the "proliferation of interest groups and diffusion of influences" among executive agencies, "multiple committee referrals" in Congress, and the possibility of judicial review and overturn have made U.S. trade policies capricious and unpredictable (see also Vernon and Spar, 1989; Destler, 1992).

The existing export subsidy programs fully confirm these diagnoses. The U.S, export enhancement program (EEP), aimed at dissuading the Europeans from subsidizing farm exports by matching their export subsidies, is an interesting case study in itself to show how the lack of clear priorities and objectives and the presence of multiple jurisdictions can paralyze a program. The program was opposed by OMB from the very beginning, and supported by the USDA, leading to infighting. The Administration's priorities changed over time, stressing economics at some points, diplomatic relations at others, and strategic advantage against the EC at yet other times. The program accommodated itself to all relevant interests, and thus served no particular interest at all. (The full story is told by 
Cloud, 1989.)

To conclude, I should emphasize that I don't pretend to have provided solutions to any of the puzzles or questions I started out with. In particular, the concepts of "policy coherence" and "state autonomy" that I have used repeatedly should be viewed as no more than descriptive categories, whose operational content still remains to be determined. What I hope I have done is to suggest that the issues that surround the question of policy effectiveness are both interesting and complicated, and that they should be a fertile ground for economists to start digging. 


\section{REFERENCES}

Amsden, Alice H., Asia's Next Giant: South Korea and Late Industrialization, New York, Oxford University Press, 1989.

Arslan, Ismail, and Sweder van Wijnbergen, "Turkey: Export Miracle or Accounting Trick?" Washington, DC, World Bank Discussion Paper WPS 370 , 1990 .

Balassa, Bela, "Export Incentives and Export Performance in Developing Countries: A Comparative Analysis," Weltwirtschaftliches Archiv, $114,1978,24-61$.

Baldwin, Robert E., The Inefficacy of Trade Policy, Princeton Essays in International Finance, No. 150, Princeton, NJ, December 1982.

Barkey, Karen, and Sunita Parikh, "Comparative Perspectives on the State," Annual Review of Sociology, 17, 1991, 523-49.

Bhagwati, Jagdish N., "The Generalized Theory of Distortions and Welfare," in Bhagwati et al., eds, Trade, Balance of Payments, and Growth, Amsterdam, North-Holland, 1971.

Bhagwati, Jagdish N., and Padma Desai, India: Planning for Industrialization, London, Oxford University Press, 1970.

Brander, James A., and Barbara J. Spencer, "Export Subsidies and International Market Share Rivalry," Journal of International Economics, 18, 1985, 83-100.

Calvo, Guillermo, "Incredible Reforms," in G. Calvo, et al., eds, Debt, Stabilization, and Development: Essays in Honor of Carlos Diaz-Alejandro, New York, Basil Blackwell, 1989.

Carmichael, Calum, "The Control of Export Credit Subsidies and its Welfare Consequences," Journal of International Economics, 23, $1987,1-19$.

Clements, Benedict J., Eoreign Trade Strategies, Employment, and Income Distribution in Brazil, New York, Praeger, 1988.

Cloud, David S., "Export Subsidies Attacked for Meeting Goal," Congressional Quarterly Weekly Report, June 24, 1989, 1531-1534.

Cetin, Bilal, Soygun: Hayali thracatın Boyutları (Hold-Up: Dimensions of Fictitious Exportingl, Ankara, Bilgi Yayınları, 1988.

De Soto, Hernando, The Other Path: The Invisible Revolution in the Third World, Harper \& Row, New York, 1989.

Destler, I.M., American Trade Politics, 2nd ed., Washington, DC, Institute for International Economics and Twentieth Century Fund, 1992 .

Dixit, Avinash, "Trade and Insurance with Adverse Selection," Review of Economic Studies, 56(2), April 1989, 235-47. 
Dixit, Avinash, "Entry and Exit Decisions under Uncertainty," Journal of Political Economy, 97, June 1989, 620-638.

Eaton, Jonathan, and Gene Grossman, "Optimal Trade and Industrial Policy under oligopoly," Quarterly Journal of Economics, 101, $1986,383-406$.

Evans, Peter, Dependent Development: The Alliance of Multinationals, State, and Local Capital in Brazil, Princeton University Press, Princeton, NJ, 1979.

Evans, Peter, "The State as Problem and Solution: Predation, Embedded Autonomy, and Structural Change," in S. Haggard and R. Kaufman, eds., The Politics of Adjustment, Princeton, NJ, Princeton University Press, 1992.

Fasano-Filho, Ugo, Bernard Fischer, and Peter Nunnenkamp, on the Determinants of Brazil's Mnaufactured Exports: An Empirical Analysis, Tubingen, J.C.B. Mohr (Paul Siebeck), 1987.

Frank, Charles R., Jr.,. Kwang Suk Kim, and Larry E. Westphal, Foreign Trade Regimes and Economic Development: South Korea, New York and London, Columbia University Press, 1975.

Frisch, Winston, and Gustavo H.B. Franco, "Brazil as an Exporter of Manufactures," unpublished manuscript, Novernber 1992.

GATT, Trade Policy Review Mechanism: Brazil, Geneva, 14 September 1992 .

GATT, Trade Policy Review Mechanism: Bolivia, Geneva, 26 February 1993.

Grossman, Gene, "Strategic Export Promotion: A Critique," in P. Krugman, ed., Strategic Trade Policy and the New International Economics, Cambridge, MA, MIT Press, 1987.

Grossman, Gene, and Elhanan Helpman, "Protection for Sale," unpublished manuscript, Princeton University, 1992.

Jones, Leroy P., and Il Sakong, Government, Business, and Entrepreneurship in Economic Development: The Korean Case, Cambridge, MA, Harvard University Press, 1980.

Jung, Woo S., and Gyu Lee, "The Effectiveness of Export Promotion Policies: The Case of Korea," Weltwirtschaftliches Archiv, CXXII, $1986,340-357$.

Krueger, Anne O., "The Political Economy of the Rent-Seeking Society," American Economic Review, 64, 1974, 291-303.

Krueger, Anne $O .$, and Okan H. Aktan, Swimming Against the Tide: Turkish Trade Reform in the 1980 s, San Francisco, ICS Press, 1992.

Krugman, Paul, "Import Protection as Export Promotion: International 
Competition in the Presence of Oligopoly and Economies of Scale," in H. Kierzkowski, ed., Monopolistic Competition in International Trade, Oxford, Oxford University Press, 1984, 180-193.

Krugman, Paul, "The Narrow and Broad Arguments for Free Trade," American Economic Review, May 1993, 362-366.

Leff, Nathaniel H., Economic Policy-Making and Development in Brazil 1947-1964, New York, John Wiley \& Sons, 1968.

Levy, Brian, "An Institutional Analysis of the Design and Sequencing of Trade and Investment Policy Reform," The World Bank Economic Review, $7(2), 1993,247-262$.

Low, Patrick, "Export Subsidies and Trade Policy: The Experience of Kenya," World Development 10(4), 1982, pp. 293-304.

Matsuyama, Kiminori, "Perfect Equilibria in a Trade Liberalization Game," American Economic Review, 80, 1990, 480-92.

McCulloch, Rachel, "The Optimality of Free Trade: Science or Religion?" American Economic Review, 83, 1993, 367-371.

Migdal, Joel, Strong Societies and Weak States, Princeton, NJ, Princeton University Press, 1988.

Milanović, Branko, Export Incentives and Turkish Manufactured Exports, 1980-1984, The World Bank, Staff Working Papers No. 768, Washington, DC, 1986.

Panagariya, Arvind, "Unravelling the Mysteries of China's Foreign Trade Regime," The World Economy, 16(1), 1993, 51-68.

Myrdal, Gunnar, Asian Drama: An Inquiry into the Poverty of Nations, New York, Pantheon, 1968.

Nogués, Julio, "The Experience of Latin America with Export Subsidies," Weltwirtschaftliches Archiv, 126(1), 1990, 97-115.

Pindyck, Robert S., and Andrés Solimano, "Economic Instability and Aggregate Investment," NBER Working Paper No. 4380, June 1993.

Rhee, Yung Whee, Bruce Ross-Larson, and Garry Pursell, Korea's Competitive Edge: Managing the Entry into World Markets, Baltimore and London, The Johns Hopkins University Press, 1984.

Richardson, J. David, "The New Political Economy of Trade Policy," in P. Krugman, ed., Strategic Trade Policy and the New International Economics, Cambridge, MA, MIT Press, 1987.

Rodrik, Dani, "Türkiye'nin thracat Patlamasının Ne Kadarı Hayali?" [How Much of the Turkish Export Boom is Fictitious?], Toplum ve Bilim, 42, Summer 1988, 133-136.

Rodrik, Dani, "Policy Uncertainty and Private Investment in Developing Countries," Journal of Development Economics, 36, 1991, 229-242. 
Rodrik, Dani, "Political Economy and Development Policy," European Economic Review, 36, 1992, 329-336.

Shapiro, Helen, "Automobiles: From Import Substitution to Export Promotion in Brazil and Mexico," in D. Yoffie, ed., Beyond Free Trade: Firms, Governments, and Global Competition,' Boston, MA, Harvard Business School Press, 1993.

Shleifer, Andrei, and Robert Vishny, "Pervasive Shortages under Socialism," NBER Working Paper No. 3791, July 1991.

Staiger, Robert W., and Guido Tabellini, "Discretionary Trade Folicy and Excessive Protection," American Economic Review, 77 (5),

Thomas, Vinod, and John Nash, Best Practices in Trade Policy Reform. New York, Oxford University Press, 1991a.

Thomas, Vinod, and John Nash, "Reform of Trade Policy: Recent Evidence from Theory and Practice," The World Bank Research Observer, 6(2), July 1991b, 219-240.

Togan, Subidey, "How to Assess the Significance of Export Incentives: An Application to Turkey, "Bilkent University, 1993 (forthcoming, Weltwirtschaftliches Archiv).

Uygur, Ercan, "Trade Policies and Economic Performance in Turkey in the 1980s," unpublished paper, Faculty of Political science, Ankara University, 1993.

Vernon, Raymond, and Debora L. Spar, Beyond Globalism: Remaking U.S. Foreign Economic Policy, New York, Free Press, 1989.

Wade, Robert, Governing the Market: Economic Theory and the Role of Princeton University Press, 1990 .

Westphal, Larry E., "Industrial Policy in an Export-Propelled Economy: Lessons from South Korea's Exprience," Journal of Economic Perspectives 4(3), Summer 1990, pp. 41-59. World Bank, Brazil: Industrial Policies and Manufactured Exports,
Washington, DC, 1983 . 